\title{
Lysine and Metabolyzable Energy Requirements of Lactating Sows for Subsequent Reproductive Performance
}

\author{
José Maurício Gonçalves dos Santos ${ }^{1 *}$, Ivan Moreira ${ }^{2}$ and Elias Nunes Martins ${ }^{2}$ \\ ${ }^{1}$ Centro Universitário de Maringá - CESUMAR; Av. Guedner, 1610; jmgds@ cesumar.br; 87050-390; Maringá - PR \\ - Brasil. ${ }^{2}$ Departamento de Zootecnia; Universidade Estadual de Maringá; Av. Colombo, 5790; 87020-900; \\ Maringá -PR - Brasil
}

\begin{abstract}
The requirements of lactating sows for total lysine and metabolyzable energy (ME) to support subsequent reproduction performance were evaluated. One hundred and twenty sows were used. The treatments were constituted of eight diets (factorial arrangement of four levels of total lysine: 0.75, 0.90, 1.05 and 1.20\%, and two levels of ME: 3,250 and 3,400 kcal ME/kg). There was interaction between lysine and ME on the plasma urea nitrogen (PUN), with linear decrease effect on level of 3,250 kcal ME/kg, and quadratic effect on level of 3,400 kcal $M E / \mathrm{kg}$, with the lowest level of PUN with $1.06 \%$ lysine. The reproductive performance in the subsequent farrowing was not affected by the lysine levels and $M E$, hence, neither the total born nor the born alive differed among the treatments. There was no convincing information to support that the requirements of total lysine and ME for lactating sows were higher than $0.75 \%$ and $3,250 \mathrm{kcal} / \mathrm{kg}$.
\end{abstract}

Key words: Feed intake, litter, plasma urea nitrogen, weaning-to-estrus interval

\section{INTRODUCTION}

Lactating sows have high nutritional requirements to support milk production. The reduced feed intake is a similar characteristic to almost all genetic lines commonly utilized in the swine industry. This may contribute to an insufficient nutrient intake to maintain a good lactation performance, with unsatisfactory productive and reproductive results. Adequate lysine and metabolizable energy (ME) intake are essential to provide an increase daily litter gain, without excessive sow body fat and protein mobilization, and with a short weaning-to-estrus interval and a large litter in the subsequent parturition. Nutritional requirements for lactating sows depend on lactation length, weight change during this phase and daily litter growth rate (NRC, 1998). Four kg of milk provided by the sow corresponds to an increase of $1 \mathrm{~kg}$ of weight by the litter (Close and Cole, 2000).

During lactation, a significant mobilization of the sow's body reserve is not desirable, because this indicates that an extensive catabolism has occurred. However, this mobilization reduces the nutritional requirements due to tissue contribution. Although a little catabolism may affect positively the LH secretion, this does not minimize the negative lactation effect on post-weaning fertility (Zak et al., 1998). The excessive body fat and protein reserves lost during lactation can also impair the subsequent reproductive performance (Close and Cole, 2000). Longer lactation period usually increases the utilization of sow's body

\footnotetext{
${ }^{*}$ Author for correspondence
} 
reserves to maintain milk production. According to Touchette et al. (1998a), an increase in litter size and milk production has a great impact on the sow's amino acids requirements. Each $\mathrm{kg}$ of litter weight gain requires approximately $25 \mathrm{~g}$ of lysine (Close and Cole, 2000). The metabolic condition influenced by nutrition and milk production may have a direct influence on post-waning reproduction (Clowes et al., 1994).

Various studies conducted to determine lysine requirements for lactating sows, and those lysine levels varied between 37 and $58 \mathrm{~g}$ daily (Touchette et al., 1998a). However, considering milk production, the energy content of the diet may affect the response of an increase protein and amino acids consumption, if energy is restricted; indicating that there is not a necessary increase in milk production (Tokach et al., 1992).

The objective of this study was to evaluate the total lysine and ME requirements of lactating sows based on lactational, post-weaning, and subsequent reproductive performance.

\section{MATERIAL AND METHODS}

This experiment was conducted at a 1,200 sows breeding herd in Northwest Paraná, Brazil, from December 2001 to May 2002. The average maximum and minimum room temperatures during this study were $26.3^{\circ} \mathrm{C}$ and $17.6^{\circ} \mathrm{C}$, respectively. At farrowing, 120 sows (Seghers ${ }^{\circledR}$ Landrace $\mathrm{x}$ Large-White) were randomly assigned to one of eight experimental diets during the lactation phase. Sows were kept in individual cages during the experimental phase and subsequent gestational period.

The chemical and energetic compositions of ingredients utilized in the experimental diets are shown in Table 1. The other ingredients used in formulations were: limestone (37.00\% of calcium), dicalcium phosphate $(22.61 \%$ of calcium and $17.03 \%$ of phosphorus) and soybean oil $(7,674$ $\mathrm{kcal} \mathrm{ME} / \mathrm{kg}$ ). A complete randomized design, with 15 experimental units (sows) per treatment was used. The eight treatments (Tables 2 and 3) were arranged in $4 \times 2$ factorial arrangement (four total lysine levels and two ME levels). The lysine levels where $0.75,0.90,1.05$ and $1.20 \%$; the ME levels where 3,250 and $3,400 \mathrm{kcal} \mathrm{ME} / \mathrm{kg}$. The lysine : methionine + cystine, lysine : threonine and lysine : tryptophan ratios met or exceeded NRC (1998). Other nutrient requirements met at least the minimum recommended requirements (NRC, 1998).

Sows were fed ad libitum with experimental diets from the first day after farrowing to weaning (an average oft 21 days). After weaning, all sows were submitted to the same feed, reproductive, and sanitary herd management. The estrous detection was initialized at weaning, using adult boars, twice daily at 07:00 AM and 04:00 PM. The semen doses were processed using rich and poor ejaculate fraction from eight boars diluted in Beltsvile Thawing Solution (BTS-IMV). Each ejaculate used had at least $80 \%$ of motility and $85 \%$ of normal spermatozoa morphology. The total number of spermatozoa was standardized in $3 \mathrm{x}$ $10^{9}$ (three billions). The storage time did not exceed $60 \mathrm{~h}$, at $15^{\circ} \mathrm{C}$. Before use, a semen dose sample was analyzed for motility, and all semen doses were discarded when motility was below $70 \%$.

The first artificial insemination was done when the sows demonstrated positive backpressure, and was repeated twice daily during subsequent estrous detection until the end of estrous. The intervals between artificial inseminations ranged from eight to 16 hours. All sows were bled $(10 \mathrm{~mL})$ at 07:00 AM, before feeding (Coma et al, 1996) in heparintubes from the anterior cava vein to determine plasma urea nitrogen (PUN) by an enzymatic method. After centrifugation $(820 \mathrm{G})$, the plasma was frozen at $-18^{\circ} \mathrm{C}$ until laboratory processing of all samples. The first sample, collected one day after farrowing, was used as a baseline PUN value, and two others samples were collected at $8^{\text {th }}$ an $15^{\text {th }}$ day post-farrowing.

Sows were weighted when moving from gestation to farrowing cages before farrowing. To obtain the post-farrowing weight, the total born litter and placenta weight was discounted from the first weight obtained. This method was adopted to avoid undesirable stress soon after farrowing. Backfat thickness (P2) was also measured one day after farrowing. At weaning, sows were weighted and the backfat thickness value obtained. All litters were equalized by the $3^{\text {rd }}$ day after farrowing, and at weaning all litter were weighted. All sows were evaluated at weaning and on subsequent farrowing reproductive performance.

The variables analyzed were: weight and backfat thickness at weaning; weight and backfat thickness change during lactation; piglet weaning weight; daily feed intake during lactation; weaning-toestrous interval; total born and born alive on 
subsequent farrowing; and PUN. All statistical analysis were computed using SAS (2000), with regression analyses and "PROC GENMOD", being admitted gamma distribution and identity link function. To analyze weight and backfat thickness at weaning, and weight and backfat thickness change during lactation, weight and backfat thickness at farrowing were used as covariates. Due to negative values, alterations in the weight and backfat thickness during lactation were added to a positive fixed number to make all values positive; this value was removed after analysis. The piglet weaning weight was corrected using lactation period as covariate, and baseline PUN value was used as a covariate for PUN analyses.

\section{RESULTS}

Ninety-eight from 120 sows initially allotted reached the subsequent farrowing. Reasons for culling before weaning were one death and two for mastits-metrits-agalactia syndrome. After weaning, six sows were culled due to lameness, five for rebreeding, three due to abortions, and two deaths. The culling of animals was not related to the experimental treatments. The results are shown in Table 4. The farrowing weight and backfat thickness did not differ among treatments. Increasing lysine and ME had no effect $(\mathrm{P}>.05)$ on the weaning weight and backfat thickness, as well as the weight and backfat thickness changes during lactation. In this study, the greater ME density led to an increase $(\mathrm{P}=.003)$ in the daily feed intake from $4.14 \mathrm{~kg}(3,250 \mathrm{kcal} \mathrm{ME} / \mathrm{kg})$ to $4.73 \mathrm{~kg}(3,400$ $\mathrm{kcal} \mathrm{ME} / \mathrm{kg}$ ); this corresponded to $13,455 \mathrm{kcal}$ ME/day and 16,082 kcal ME/day, respectively.

Piglet weaning weight (ranging between 6.2 and $6.5 \mathrm{~kg} / \mathrm{pig})$ was not influenced $(\mathrm{P}>.05)$ by lysine and/or ME levels. Weaning-to-estrous interval ranged between 4.2 and 5.9 days, and was not influenced $(\mathrm{P}>.05)$ by lysine and ME levels. Dietary lysine and ME levels did not influenced (P>.05) total born and born alive piglets at subsequent farrowing. In the present study, lower PUN concentrations occurred in the higher lysine intake, ranging between 40.6 to $49.6 \mathrm{~g}$ of lysine/day. This study showed an interaction $(\mathrm{P}=.002)$ between lysine and ME levels on PUN value. The 3,250 $\mathrm{kcal} \mathrm{EM} / \mathrm{kg}$ level had a linear effect $\hat{Y}=41.5-15.14$ lysine $\left(\mathrm{P}=.007 ; \mathrm{r}^{2}=.97\right)$, and $3,400 \mathrm{kcal} \mathrm{EM} / \mathrm{kg}$ level had a quadratic effect $\hat{\mathrm{Y}}=$ $128.39-199.23$ lysine + 94.23 lysine $^{2}(\mathrm{P}=.04$; $\mathrm{r}^{2}=.98$ ), which provided lower PUN value at $1.06 \%$ of dietary lysine.

Table 1 - Chemical and energetic composition of the ingredients used in the experimental diets ${ }^{1}$

\begin{tabular}{|c|c|c|c|c|c|c|}
\hline \multirow[b]{2}{*}{ Nutrients, \% } & \multicolumn{6}{|c|}{ Ingredients } \\
\hline & Corn & $\begin{array}{c}\text { Soybean } \\
\text { meal }\end{array}$ & $\begin{array}{c}\text { L-Lysine } \\
\text { HCl }\end{array}$ & $\begin{array}{c}\text { DL- } \\
\text { Methionine }\end{array}$ & L-Threonine & L-Tryptophan \\
\hline Crude protein, $\%$ & 8.51 & 45.60 & 93.40 & 58.10 & 72.00 & 84.00 \\
\hline $\begin{array}{l}\text { Metabolizable energy, } \\
\mathrm{kcal} / \mathrm{kg}\end{array}$ & 3,369 & 3,081 & 4,470 & 5,280 & 3,700 & 6,300 \\
\hline Lysine, $\%$ & .23 & 2.87 & 78.00 & - & - & - \\
\hline Methionine + cystine, $\%$ & .35 & 1.34 & - & 99.00 & - & - \\
\hline Threonine, $\%$ & .34 & 1.78 & - & - & 98.00 & - \\
\hline Tryptophan, \% & .08 & .67 & - & - & - & 98.00 \\
\hline Ether extract, $\%$ & 3.28 & .79 & - & - & - & - \\
\hline Crude fiber, $\%$ & 1.78 & 6.46 & - & - & - & - \\
\hline Calcium, \% & .02 & .36 & - & - & - & - \\
\hline Total phosphorus, $\%$ & .27 & .55 & - & - & - & - \\
\hline
\end{tabular}

1 -Based on Rostagno et al. (1985), Ajinomoto (2000), and Degussa (2000) 
Table 2 - Centesimal composition of the experimental diets

\begin{tabular}{lcccccccc}
\hline Treatment & $\mathbf{1}$ & $\mathbf{2}$ & $\mathbf{3}$ & $\mathbf{4}$ & $\mathbf{5}$ & $\mathbf{6}$ & $\mathbf{7}$ & $\mathbf{8}$ \\
\hline Metabolizable energy, kcal/kg & \multicolumn{3}{c}{$\mathbf{3 , 2 5 0}$} & & & & $\mathbf{3 , 4 0 0}$ & \\
\hline Lysine, \% & .75 & .90 & 1.05 & 1.20 & .75 & .90 & 1.05 & 1.20 \\
\hline Corn, \% & 74.65 & 74.82 & 75.18 & 75.91 & 70.82 & 70.43 & 70.79 & 71.50 \\
Soybean meal, \% & 20.15 & 19.83 & 19.29 & 18.36 & 20.46 & 20.68 & 20.14 & 19.23 \\
Limestone, \% & .86 & .86 & .86 & .87 & .82 & .82 & .82 & .84 \\
Dicalcium & & & & & & & & \\
phosphate, \% & 1.85 & 1.86 & 1.87 & 1.84 & 1.90 & 1.90 & 1.91 & 1.88 \\
Soybean oil, \% & 1.49 & 1.43 & 1.35 & 1.14 & 5.00 & 4.98 & 4.89 & 4.70 \\
Salt, \% & .50 & .50 & .50 & .50 & .50 & .50 & .50 & .50 \\
L-lysine HCl, \% & - & .20 & .41 & .64 & - & .19 & .40 & .62 \\
DL-methionine, \% & - & - & .02 & .07 & - & - & .03 & .07 \\
L-threonine, \% & - & - & .02 & .13 & - & - & .02 & .13 \\
L-tryptophan, \% & - & - & - & .04 & - & - & - & .03 \\
Vitamin premix ${ }^{1}, \%$ & .40 & .40 & .40 & .40 & .40 & .40 & .40 & .40 \\
Mineral premix ${ }^{2}, \%$ & .10 & .10 & .10 & .10 & .10 & .10 & .10 & .10 \\
\hline
\end{tabular}

1 -Premix composition/kg: retinol $75 \mathrm{mg}$ (1 mg retinol is 3,333 IU vitamin A), cholecalciferol $1 \mathrm{mg}$ (1 mg cholecalciferol is 40,000 IU vitamin D3), DL alpha tocopherol acetate $350 \mathrm{mg}$ (1 $\mathrm{mg}$ DL alpha tocopherol acetate is $1 \mathrm{IU}$ vitamin E), menadione $70 \mathrm{mg}$, tiamin $25 \mathrm{mg}$, riboflavin $100 \mathrm{mg}$, piridoxin $25 \mathrm{mg}$, niacin $900 \mathrm{mg}$, calcium panthotenate $400 \mathrm{mg}$, folic acid $10 \mathrm{mg}$, biotin $2,5 \mathrm{mg}$, vitamin B12 $600 \mathrm{mg}$, coline $5.000 \mu \mathrm{g}$, antioxidant $10,000 \mathrm{mg}$.

2 -Premix composition/kg: cobalt $10 \mathrm{mg}$, copper $350 \mathrm{mg}$, iron 1,500 mg, iodine $20 \mathrm{mg}$, manganese 1,500 mg, selenium $4 \mathrm{mg}$, zinc $2,500 \mathrm{mg}$.

Table 3 - Chemical composition of the experimental diets ${ }^{1}$

\begin{tabular}{lrrrrrrrr}
\hline Treatment & $\mathbf{1}$ & $\mathbf{2}$ & $\mathbf{3}$ & $\mathbf{4}$ & $\mathbf{5}$ & $\mathbf{6}$ & $\mathbf{7}$ & $\mathbf{8}$ \\
\hline $\begin{array}{l}\text { Metabolizable energy, } \\
\text { kcal/kg }\end{array}$ & \multicolumn{2}{c}{$\mathbf{3 , 2 5 0}$} & & & & $\mathbf{3 , 4 0 0}$ & \\
\hline Lysine, \% & $\mathbf{. 7 5}$ & $\mathbf{. 9 0}$ & $\mathbf{1 . 0 5}$ & $\mathbf{1 . 2 0}$ & $\mathbf{. 7 5}$ & $\mathbf{. 9 0}$ & $\mathbf{1 . 0 5}$ & $\mathbf{1 . 2 0}$ \\
\hline Crude protein, \% & 15.54 & 15.60 & 15.60 & 15.60 & 15.36 & 15.60 & 15.60 & 15.60 \\
Ether extract, \% & 4.10 & 4.04 & 3.97 & 3.78 & 7.48 & 7.45 & 7.37 & 7.20 \\
Crude fiber, \% & 2.63 & 2.61 & 2.58 & 2.54 & 2.58 & 2.59 & 2.56 & 2.52 \\
Methionine + cystine, \% & .53 & .53 & .54 & .58 & .52 & .52 & .55 & .58 \\
Threonine, \% & .61 & .61 & .62 & .71 & .61 & .61 & .62 & .71 \\
Tryptophan, \% & .19 & .19 & .19 & .22 & .19 & .19 & .19 & .22 \\
Calcium, \% & .82 & .82 & .82 & .82 & .82 & .82 & .82 & .82 \\
Total phosphorus, \% & .62 & .62 & .62 & .62 & .62 & .62 & .62 & .62 \\
\hline -Calcury
\end{tabular}

1 -Calculated values based on Tables 1 and 2.

\section{DISCUSSION}

The weight and backfat thickness changes observed in sows during lactation are related to a reduced feed intake, which do not meet the nutritional requirements for maintenance and milk production. The severity of weight and backfat thickness losses has been related to lactation period, litter size and weight gain, sow body composition at farrowing, parity order, and environmental conditions (Close and Cole, 2000). According to Close and Cole (2000), an increased energy intake can minimize this variation in weight and backfat thickness. The results of the present study showed that feed energy density could be an important factor to reduce the negative impact of lactation on sow weight and backfat thickness loss. However, daily ME intake observed in all diets were bellow the minimum recommended by NRC (1998) to lactating sows, $17,135 \mathrm{kcal}$ ME/day. Feed intake tends to be controlled by several factors (NRC, 1998): physiological (genetic, neuro-hormonal, and sensitive); environmental (temperature, humidity, animal density, group size); and dietary (nutrients deficiency or excess, flavors, antibiotics, availability and quantity of water, feed processing, and energy density). 
Table 4 - Estimated means of productive, and reproductive performance, and blood parameters of lactating sows fed experimental diets ${ }^{1}$

\begin{tabular}{|c|c|c|c|c|c|c|c|c|}
\hline Treatment & 1 & 2 & 3 & 4 & 5 & 6 & 7 & 8 \\
\hline $\begin{array}{l}\text { Metabolizable energy, } \\
\text { kcal/kg }\end{array}$ & \multicolumn{4}{|c|}{3,250} & \multicolumn{4}{|c|}{3,400} \\
\hline Lysine, \% & .75 & .90 & 1.05 & 1.20 & .75 & .90 & 1.05 & 1.20 \\
\hline Farrowing weight, kg & $\begin{array}{c}248.5 \pm \\
10.1\end{array}$ & $\begin{array}{l}261.2 \pm \\
10.4\end{array}$ & $\begin{array}{l}265.2 \pm \\
11.4\end{array}$ & $\begin{array}{l}271.1 \pm \\
8.9\end{array}$ & $\begin{array}{l}255.5 \\
\pm 12.7\end{array}$ & $\begin{array}{l}271.0 \pm \\
11.2\end{array}$ & $\begin{array}{l}261.7 \pm \\
9.6\end{array}$ & $\begin{array}{l}259.7 \pm \\
8.3\end{array}$ \\
\hline Weaning weight, kg & $\begin{array}{l}229.6 \pm \\
10.0\end{array}$ & $\begin{array}{c}239.8 \pm \\
10.2\end{array}$ & $\begin{array}{l}242.9 \pm \\
12.6\end{array}$ & $\begin{array}{c}247.2 \pm \\
7.7\end{array}$ & $\begin{array}{l}233.4 \\
\pm 12.0\end{array}$ & $\begin{array}{c}249.5 \pm \\
10.1\end{array}$ & $\begin{array}{c}239.4 \pm \\
11.1\end{array}$ & $\begin{array}{c}240.8 \pm \\
8.9\end{array}$ \\
\hline Weight change, $\mathrm{kg}$ & $\begin{array}{c}-18.9 \pm \\
4.1\end{array}$ & $\begin{array}{c}-21.4 \pm \\
2.8\end{array}$ & $\begin{array}{c}-22.3 \pm \\
2.9\end{array}$ & $-30.8 \pm 6.8$ & $\begin{array}{c}-22.1 \pm \\
2.5\end{array}$ & $\begin{array}{c}-21.5 \pm \\
3.4\end{array}$ & $\begin{array}{c}-27.8 \pm \\
4.7\end{array}$ & $\begin{array}{c}-18.8 \pm \\
2.4\end{array}$ \\
\hline $\begin{array}{l}\text { Farrowing backfat } \\
\text { thickness, mm }\end{array}$ & $\begin{array}{c}22.3 \pm \\
1.5\end{array}$ & $\begin{array}{c}22.6 \pm \\
1.6\end{array}$ & $\begin{array}{c}22.7 \pm \\
1.2\end{array}$ & $22.1 \pm 1.0$ & $\begin{array}{c}23.7 \pm \\
1.0\end{array}$ & $\begin{array}{c}21.6 \pm \\
1.0\end{array}$ & $\begin{array}{c}20.7 \pm \\
0.9\end{array}$ & $\begin{array}{c}20.9 \pm \\
0.7\end{array}$ \\
\hline $\begin{array}{l}\text { Weaning backfat } \\
\text { thickness, mm }\end{array}$ & $\begin{array}{c}19.4 \pm \\
1.1\end{array}$ & $\begin{array}{c}20.3 \pm \\
1.4\end{array}$ & $\begin{array}{c}20.9 \pm \\
1.0\end{array}$ & $20.1 \pm 1.3$ & $\begin{array}{c}19.9 \pm \\
1.3\end{array}$ & $\begin{array}{c}19.6 \pm \\
1.0\end{array}$ & $\begin{array}{c}20.0 \pm \\
0.7\end{array}$ & $\begin{array}{c}19.6 \pm \\
0.8\end{array}$ \\
\hline $\begin{array}{l}\text { Backfat thickness change, } \\
\mathrm{mm}\end{array}$ & $\begin{array}{l}-2.9 \pm \\
1.4\end{array}$ & $\begin{array}{c}-2.3 \pm \\
0.8\end{array}$ & $\begin{array}{c}-1.8 \pm \\
1.1\end{array}$ & $-2.0 \pm 1.2$ & $\begin{array}{c}-3.7 \pm \\
1.1\end{array}$ & $\begin{array}{c}-2.1 \pm \\
1.0\end{array}$ & $\begin{array}{c}-0.7 \pm \\
0.8\end{array}$ & $\begin{array}{c}-1.3 \pm \\
0.5\end{array}$ \\
\hline Daily feed intake ${ }^{2}, \mathrm{~kg}$ & $\begin{array}{c}4.05 \pm \\
0.2\end{array}$ & $\begin{array}{c}4.32 \pm \\
0.3\end{array}$ & $\begin{array}{c}4.40 \pm \\
0.3\end{array}$ & $3.84 \pm 0.3$ & $\begin{array}{c}4.33 \pm \\
0.4\end{array}$ & $\begin{array}{l}5.31 \pm \\
0.5\end{array}$ & $\begin{array}{c}4.87 \pm \\
0.3\end{array}$ & $\begin{array}{c}4.40 \pm \\
0.2\end{array}$ \\
\hline Weaned piglet weight, $\mathrm{kg}$ & $\begin{array}{c}6.46 \pm \\
0.3\end{array}$ & $\begin{array}{c}6.27 \pm \\
0.2\end{array}$ & $\begin{array}{c}6.23 \pm \\
0.3\end{array}$ & $6.56 \pm 0.2$ & $\begin{array}{c}6.39 \pm \\
0.2\end{array}$ & $\begin{array}{c}6.15 \pm \\
0.3\end{array}$ & $\begin{array}{c}6.50 \pm \\
0.2\end{array}$ & $\begin{array}{c}6.50 \pm \\
0.3\end{array}$ \\
\hline $\begin{array}{l}\text { Weaning to estrus } \\
\text { interval, days }\end{array}$ & $4.9 \pm 0.3$ & $4.4 \pm 0.2$ & $5.9 \pm 0.2$ & $4.8 \pm 0.3$ & $\begin{array}{c}4.2 \pm \\
0.3\end{array}$ & $5.6 \pm 0.2$ & $5.4 \pm 0.2$ & $4.3 \pm 0.2$ \\
\hline Total Born & $\begin{array}{c}10.8 \pm \\
0.6\end{array}$ & $\begin{array}{c}10.4 \pm \\
0.6\end{array}$ & $\begin{array}{c}11.5 \pm \\
0.4\end{array}$ & $11.3 \pm 0.6$ & $\begin{array}{c}11.1 \pm \\
0.7\end{array}$ & $\begin{array}{c}11.3 \pm \\
0.5\end{array}$ & $\begin{array}{c}11.1 \pm \\
0.5\end{array}$ & $\begin{array}{c}10.4 \pm \\
0.3\end{array}$ \\
\hline Born alive & $9.6 \pm 0.8$ & $9.9 \pm 0.8$ & $\begin{array}{c}10.2 \pm \\
0.7\end{array}$ & $9.8 \pm 0.8$ & $\begin{array}{c}9.8 \pm \\
0.9\end{array}$ & $\begin{array}{c}10.4 \pm \\
0.6\end{array}$ & $\begin{array}{c}10.8 \pm \\
0.6\end{array}$ & $9.7 \pm 0.5$ \\
\hline \multicolumn{9}{|l|}{$\begin{array}{l}\text { Plasma urea nitrogen, } \\
\mathrm{mg} / \mathrm{dL}\end{array}$} \\
\hline 8th day post-farrowing & $\begin{array}{c}27.0 \pm \\
1.8\end{array}$ & $\begin{array}{c}21.1 \pm \\
1.6\end{array}$ & $\begin{array}{c}28.9 \pm \\
1.8\end{array}$ & $22.6 \pm 1.8$ & $\begin{array}{c}26.9 \pm \\
1.3\end{array}$ & $\begin{array}{c}25.7 \pm \\
2.0\end{array}$ & $\begin{array}{c}21.9 \pm \\
1.7\end{array}$ & $\begin{array}{c}25.1 \pm \\
1.6\end{array}$ \\
\hline 15 th day post-farrowing ${ }^{3}$ & $\begin{array}{c}31.5 \pm \\
2.1 \\
\end{array}$ & $\begin{array}{c}26.5 \pm \\
2.2 \\
\end{array}$ & $\begin{array}{c}26.0 \pm \\
1.4\end{array}$ & $22.9 \pm 1.7$ & $\begin{array}{c}32.3 \pm \\
1.7 \\
\end{array}$ & $\begin{array}{c}25.4 \pm \\
1.6 \\
\end{array}$ & $\begin{array}{c}23.5 \pm \\
2.3\end{array}$ & $\begin{array}{c}23.7 \pm \\
2.1\end{array}$ \\
\hline
\end{tabular}

Of the dietary factors mentioned, elevated energy density normally reduces feed intake. However, in this study this reductive effect was not observed, because the higher energy density also resulted in higher feed intake, possibly due to a flavor effect and a reduced amount of dust due to oil addition. Dourmad et al. (1998) using isoenergetic lactation diets with two crude protein levels and L-lysine$\mathrm{HCl}$ supplementation did not report any backfat thickness differences. However, these authors indicated that sows fed the lowest lysine level $(.66 \%)$ lost more weight during lactation.

In lactation diets with different levels of crude protein and L-lysine- $\mathrm{HCl}$ supplementation under commercial conditions, Touchette et al. (1998b) suggested that an addition of more than $.075 \%$ of this synthetic amino acid could increase preweaning mortality and decrease the number of piglets weaned. Neither this effect nor an improvement in reproductive parameters was observed in this study. The piglet weaning weight of the present study were similar to those observed by Touchette et al. (1998b) and Thaler et al. (1992) who reported no improvement on litter performance with greater lysine intake. However, Stahly et al. (1990) and Johnston et al. (1993) reported a positive effect of not only lysine but also protein intake during lactation on litter weight gain. 
A possible explanation for this lack of response to increasing levels of lysine on sow's weight and backfat thickness change, and litter performance (even with the adding of DL-methionine, Ltreonine and, L-tryptophan to meet balance in the diets) could be related to a lack of other limiting amino acids (Touchette et al., 1998b), such as valine and isoleucine (Richert et al., 1997). Besides, the amino acids absorption process in small intestine may become relatively less effective when high amounts of synthetic amino acids are added to the diet. The enterocytes absorb amino acids in one of the three forms mono-, di-, or tripeptide; but di and tri are considered the most effective (Cunninghan, 1999). Synthetic amino acids, exclusively monopeptide, may saturate the amino acids transportation mechanisms, being two or three times less effective.

The weaning-to-estrous interval is directly related to lactation period (lactation length, nutritional and feeding strategies, parity, litter number, weight and backfat thickness change), facilities, genetics, and season (Zak et al., 1997; Vesseur et al. 1994a; Koketsu, et al., 1996), as well as estrous detection and reproductive management. In this study, an increase in feed intake did not reduce the weaningto-estrous interval. King and Dunkin (1986) reported a positive linear effect of ME feed intake on the weaning-to-estrous interval. Vesseur et al. (1994b) reviewed the possible direct effects of the weaning-to-estrous interval on reproductive performance, and concluded that a short weaningto-estrous interval tended to result in more large litters. However, this evaluation could be biased, since weaning-to-estrous interval was not a cause, but a result of the effects of nutrition and metabolism on reproduction.

Touchette et al. (1998a) evaluated first parity sows fed different lysine levels, keeping the ideal amino acids ratios constant by adding valine, treonine, and sulfur amino acids. The increasing intake of lysine and other synthetic amino acids resulted in a reduced number of total and born alive piglets on subsequent farrowing. The addition of lysine, but not other synthetic amino acids increased litter size. Zak et al. (1997) reported a negative effect of low feed intake during lactation on ovulation rate and embryo survival, which might influence litter size. However, this effect may be reduced due to weaning-to-estrus interval feed intake, especially in wide intervals. In part, this improvement is related to insulin, IGF-I (insulin growth-like factor), and LH plasma levels, because these hormones show a positive response to increasing feed intake (Zak et al., 1997; Beltranena et al., 1991). When there is a high post-weaning feed intake, the liver blood flow may be enhanced, which provide an increased progesterone clearance rate (Foxcroft et al., 1996). However, this clearance process was observed after and not before mating (Jindal et al., 1996). Coma et al. (1996) obtained the lowest PUN concentration in lactating sows with an intake of $55.3 \mathrm{~g}$ of lysine/day. Even the 3,250 and 3,400 kcal ME/kg as lysine levels of $0.75 \%, 0.90 \%, 1.05 \%$ and $1.20 \%$ seemed to meet lactating sow's requirements for subsequent litter size. The results indicated no benefit of total lysine and ME intake greater than $0.75 \%$ and $3,250 \mathrm{kcal} / \mathrm{kg}$ for lactating sows.

\section{ACKNOWLEDGEMENTS}

The authors would like to thank Raçalto Brasil Agropecuária Ltda for supplying the animals and facilities.

\section{RESUMO}

Foram avaliadas as exigências de lisina total e energia metabolizável (EM) para porcas em lactação visando o desempenho reprodutivo subseqüente. Cento e vinte porcas foram utilizadas. Os tratamentos foram constituídos de oito dietas (arranjo fatorial de quatro níveis de lisina: 0,$75 ; 0,90 ; 1,05$ e $1,20 \%$ e dois níveis de EM: 3.250 e $3.400 \mathrm{kcal}$ EM/kg). Houve interação entre lisina e EM quanto ao nitrogênio da uréia plasmática (NUP), com diminuição linear para o nível de $3.250 \mathrm{kcal} \mathrm{EM} / \mathrm{kg}$ e efeito quadrático para o nível de $3.400 \mathrm{kcal} \mathrm{EM} / \mathrm{kg}$, com o menor concentração de NUP em $1,06 \%$ de lisina. O Desempenho reprodutivo no parto subseqüiente não foi afetado pelos níveis de lisina e EM, assim como o número de leitões nascidos totais ou vivos diferiu entre os tratamentos. Não houve informações convincentes de que as exigências de lisina total e EM para porcas em lactação sejam maiores que $0,75 \%$ e $3.250 \mathrm{kcal} \mathrm{EM} / \mathrm{kg}$. 


\section{REFERENCES}

Ajinomoto (2000), Ajinomoto Animal Nutrition. http://www.lisina.com.br.

Beltranena, E.; Aherne, F. X.; Foxcroft, G. R. and Kirkwood, R. N. (1991), Effects of pre- and postpubertal feeding on production traits at first and second estrus in gilts. J. Anim. Sci., 69, 886-893.

Close, W. H. and Cole, D. J. A. (2000), Nutrition of sows and boars. Trumpton: Nottinghan University. 373 pp.

Clowes, E. J.; Aherne, F. X. and Foxcroft, G. R. (1994), Effect of delayed breeding on the endocrinology and fecundity of sows. J. Anim. Sci., 72, 283-291.

Coma, J.; Zimmerman, D. R. and Carrion, D. (1996), Lysine requirement of the lactating sow determined by using plasma urea nitrogen as a rapid response criterion. J. Anim. Sci., 74, 1056-1062.

Cunninghan, J. G. (1999), Digestão e absorção: os processos não-fermentativos. In: Tratado de Fisiologia Veterinária. 2. ed. Rio de Janeiro: Guanabara Koogan. pp. 242-265.

Degussa (2000), Degussa feed additives. http://www.aminoacidsandmore.com.

Dourmad, J. Y.; Noblet, J. and Étienne, M. (1998), Effect of protein and lysine supply on performance, nitrogen balance, and body composition changes of sows during lactation. J. Anim. Sci., 76, 542-550.

Foxcroft, G. R. and Cosgrove, J. R. (1996), Aherne, F. $X$. The interface between reproduction and the nutrition in swine. Papper presented at 2. Conferência internacional sobre ciência e tecnologia de produção e industrialização de suínos. Campinas, São Paulo. pp. 54-66,

Jindal, R.; Cosgrove, J. R.; Aherne, F. X. and Foxcroft, G. R. (1996), Effect of nutrition on embryonal mortality in gilts: Association with progesterone. $J$. Anim. Sci., 74, 620-624.

Johnston, L. J.; Pettigrew, J. E. and Rust, J. W. (1993), Responses of maternal-line sows to dietary protein concentration during lactation. J. Anim. Sci., 71, 2151-2156.

King, R. H. and Dunkin, A. C. (1986), The effect of nutrition on the reproductive performance of first litter sows. 3. The response to graded increases in food intake during lactation. Anim. Prod., 42, 119-125.

Koketsu, Y.; Dial, G. D.; Pettigrew, J. E.; Marsh, W. E. and King, V. L. (1996), Influence of imposed feed intake patterns during lactation on subsequent performance and on circulating levels of glucose, insulin, and luteinizing hormone in primiparous sows. J. Anim. Sci., 74, 1036-1046.

NRC (1998), Nutrient Requirement of Swine. 10. rev. ed. Washington: Subcommittee on Swine Nutrition. $210 \mathrm{pp}$.
Richert, B. T.; Goodband, R. D.; Tokach, M. D. and Nelssen, J. L. (1997), Increasing valine, isoleucine, and total branched-chain amino acids for lactating sows. J. Anim. Sci., 75, 2117-2128.

Rostagno, H. S.; Silva, D. J.; Costa, P. M. A.; Fonseca, J. B.; Soares, P. R.; Pereira, J. A. A. and Silva, M. A. (1992), Composição de alimentos e exigências nutricionais de aves e suínos (tabelas brasileiras). Viçosa: UFV. 60 pp.

Sas Institute Inc. (2000), Statistical Analysis System, Version 8.0. Cary, NC (Manual On-line).

Sthaly, T. S.; Cromwell, G. L. and Monegue, H. J. (1990), Lactational responses of sows nursing large litters to dietary lysine levels. J. Anim. Sci., 68 : (suppl. 1), 369.

Thaler, R. C.; Woerman, R. L. and Britzman, D. B. (1992), Effect of lysine level in lactation diets on sow performance and milk composition. J. Anim. Sci., 70 : (suppl. 1), 238.

Tokach, M. D.; Pettgrew, J. E.; Crooker, B. A.; Dial, G. D. and Sower, A. F. (1992), Quantitative influence of lysine and energy intake on yield of milk components in the primiparous sow. J. Anim. Sci., 70, 1864-1872.

Touchette, K. J.; Allee, G. L.; Newcomb, M. D. and Boyd, R. D. (1998a), The lysine requirement of lactating primiparous sows. J. Anim. Sci., 76, 10911097.

Touchette, K. J.; Allee, G. L.; Newcomb, M. D. and Boyd, R. D. (1998b), The use of synthetic lysine in the diet of lactating sows. J. Anim. Sci., 76, 1437-1442.

Vesseur, P. C.; Kemp, B. and Den Hartog, L. A. (1994a), Factors affecting the weaning to oestrus interval in the sow. Journal of Animal Physiology and Animal Nutrition, 72, 225-233.

Vesseur, P. C.; Kemp, B. and Den Hartog, L. A. (1994b), The effect of weaning to oestrus interval on litter size, live born piglets and farrowing rate in sows. Journal of Animal Physiology and Animal Nutrition, 71, 30-38.

Zak, L. J.; Cosgrove, J. R.; Aherne, F. X. and Foxcroft, G. R. (1997), Pattern of feed intake and associated metabolic and endocrine changes, differentially affect post-weaning fertility in the primiparous sows. $J$. Anim. Sci., 75, 208-216.

Zak, L. J.; Wiliams, I. H.; Foxcroft, G. R.; Pluske, J. R.; Cegielski, A. C.; Clowes, E. J. and Aherne, F. X. (1998), Feeding lactating primiparous sows to establish three divergent metabolic states: I. Associated endocrine changes and postweaning reproductive performance. J. Anim. Sci., 76, 1145-1153.

Received: December 09, 2004; Revised: October 03, 2005; Accepted: March 30, 2006. 